\title{
An initial study in the development of smartphone addiction scale for student (SAS-S)
}

\author{
A.Maulani Habibi ${ }^{*} 1$, Sigit Sanyata ${ }^{2}$ \\ ${ }^{12}$ Universitas Negeri Yogyakarta \\ ${ }^{*}$ Corresponding author, ఏe-mail: 01maulanihabibi@gmail.com
}

\begin{abstract}
The purpose of this study was to develop a new scale, Smartphone Addiction Scale for Student (SAS-S) was developed to measure the level of smartphone addiction in high school students. A total of 32 item scales were developed through literature studies. Exploratory factor analysis (EFA) is used to examine the structure of factors formed in this scale. The results show the Smartphone addiction scale for Student (SAS-S) has 22 good items from 6 factor structures that are formed, including: (1) Self Control Disorder, (2) loss of time, (3) sleep disturbances, (4) can not be without smartphones, (5) changes in feelings and, (6) concerned smartphone. SAS-S is a good scale that can be used by any high school student. Another point also shows that the scale of smartphone addiction for high school students has a strong level of validity and reliability.
\end{abstract}

Keywords: exploratory factor analysis (EFA); smartphone addiction scale for student (SAS-S).

How to Cite: Habibi, A. M \& Sanyata, S. (2018). An Initial Study In the Development of Smartphone Addiction Scale for Student (SAS-S). Couns-Edu: International Journal of Counseling and Education, 3(3): pp. 93-100. DOI: https://doi.org/10.23916/0020180315730

This is an open access article distributed under the Creative Commons Attribution License, which permits unrestricted use, distribution, and reproduction in any medium, provided the original work is properly cited. ( 2018 by author.

\section{Introduction}

The use of smartphones today has become a trend among the public. According to Gary smartphones to be different from ordinary mobile phones, this is because smartphones have variants and advantages in operational systems (Karuniawan \& Cahyanti, 2013). Currently smartphone users have increased in the Indonesian community. Based on research data digital marketing emarketer estimates in 2018 the number of active users of smartphones in Indonesia more than 100 million people (Rahmayani, 2015).

Smartphones now have become an item with a high level of need for some people, this is in an effort to support their work productivity (Jocom, 2013). The advantages of the smartphone is no doubt, a variety of features and applications inside are able to make it convenient to use. Currently smartphone users are not only adults only, but students in high schools are also many who use smartphones.

The use of smartphones among high school students today is no wonder, many students take advantage of smartphones as a medium of communication and information in his life. Such as learning media at home. Sophistication possessed by the smartphone of course not only give good impact for its users but also give bad impact. As Ciu in his research found that individuals who can not control themselves in using smartphones will cause themselves to be addicted to smartphones (Karuniawan \& 
Cahyanti, 2013). Excessive smartphone usage has indicators similar to indicators of alcohol and drug addiction (Yildiz, 2017).

Smartphone addictions is one of the same symptoms with other addictive symptoms. Desouky (2016) in his study found there is a positive relationship between addiction smartphones and internet addiction (Yildiz, 2017). The use of internet and smartphones has almost the same characteristics and also has the same impact. As also conveyed by Young and Rogers in (Dewi \& Trikusumaadi, 2016) that the negative impact of the internet makes a person lazy to interact in the real world because it feels more fun to interact with friends online resulting in a lack of empathy towards the surrounding environment.

Excessive smartphone use can cause personal and social problems (Choi et al., 2017). The problem of addiction to this smartphone has been found by researchers in various countries, such as research conducted on 414 students in China, there are 5 symptoms that arise in individuals with addiction to the smartphone that is preoccupation, inability to control the desire, loss of productivity, and feel anxious and lost (Bian \& Leung, 2015). This problem is supported also with the results of research done (Duke \& Montag, 2017) who found out of 262 smartphone users there is a positive relationship between smartphone addiction with disruption of daily activities. Individuals with smartphone addiction have less productivity when they are at home or at work.

Addiction is an abstract concept, just like love and justice, with no limit in defining it (West \& Brown, 2013). Then define an addicted individual is an individual who is experiencing a disruption of control over his behavior to a level that causes or can cause bad harm to himself (West \& Brown, 2013). The current level of technological development has changed the definition of addiction, no longer on the contention of a substance or food, but now also includes behavioral addictions, such as gambling behavior, internet, gaming, even addiction to smartphones (Matar Boumosleh \& Jaalouk, 2017). This is in line with (Padwa \& Cunhingham, 2010) that addiction is no longer about substance and alcohol, but addiction is also to behavior, such as gambling, eating, sex, shopping and internet behavior. The development of today's technology smartphones has indeed made people comfortable and happy in using it, in addition to eliminate boredom, smartphone can also adversely affect the users.

Addiction to smartphones is the behavior of individuals who too often use a smartphone that can Claim the lives of everyday users (Demirci, Orhan, Demirdas, Akpinar, \& Sert, 2014). The loss of time and concentration in learning is one of the most remarkable effects for students when overuse of smartphones.

Based on the issue of smartphone addiction, it will certainly cause concern to students who are vulnerable to having an addiction smartphone. This of course can disrupt the learning process of students at school and at home, as well as affect its development. In addition to interfering with the daily activities of a smartphone addiction can also have some negative impact on students such as increasing loneliness and depression, trigger anxiety, increased stress, aggravate attention disorders, reduce concentration, disturb sleep and encourage self-absorption (Smith, Robinson, \& Segal, 2017) .

Regardless of the amount of research on smartphone addiction, it needs a scale development that can measure smartphone addiction in high school students. Currently there has been a lot of developing measuring tools against smartphone addiction, but the scale is not necessarily applicable and really measure the addiction of smartphones in high school students in Indonesia. Just as the smartphone addiction scale (SAS) of (Kwon, Kim, Cho, \& Yang, 2013) is still neglected and has not yet comfrehensively measured the student's smartphone addiction. Then another scale is also developed by (Lin et al., 2014) called Smartphone Addiction Inventory (SPAI), this scale has four factors: compulsive behavior, functional impairment, withdrawal and tolerance. Furthermore, the scaling of Iowa State University with 20 statement points that only concerns when the smartphone can not be used, this does not reveal the whole form of addiction itself. Additionally scales have been developing the west may not necessarily be applied to the culture in Indonesia, considering the culture and traditions of the world community are different. Other measuring tools are also developed by (Lee, Ahn, Choi, \& Choi, 2014) called The SAMS (Smartphone Addiction Management System and Verification). This measuring tool is developed based on the application on the smartphone. This tool can only be used when the online system 
and only measure the indicator of the number of uses, but does not assess other indicators of the concept of smartphone addiction. So it can be said this gauge does not measure fully about the addiction of smartphones. Based on this problem researchers are interested in developing a scale that can measure the level of smartphone addiction in high-school students.

\section{Method}

The research method used in this research is psychometric, that is developing the smartphone addiction scale for Student (SAS-S). This study is a preliminary study of SAS-S development. The analysis factor was performed as part of the initial development of this scale. Prior to factor analysis, this scale has been performed content validation (expert judgment) with two experts in the field of psychology. Factor analysis in this research using exploratory factor analysis (EFA). Exploratory factor analysis (EFA) was used to see the structure factor formed on the scale (Khan, 2006) in (Gaol \& Lin, 2017). Therefore, this study will determine the factor structures formed by EFA test. When using exploratory factor analysis (EFA), Costello \& Osborne (2005) in (Wahyuningsih, 2009) suggests to use principal axis factors as an extraction method and use eigenvalues greater than 1.0 to determine the number of factors. The data collection in this study was done by spreading the scale that has been validated the contents of 32 items given to 271 high school students with an average age of 16 and 17 years.

\section{Result and Discussion}

Exploratory factor analysis (EFA) is used to be able to see the structure factor that is formed from the smartphone addiction scale for students (SAS-S). Based on these tests it is known as 10 items wasted scale from the initial 32 items, so that eligible EFA test as much as 22 items the scale of addiction smartphones for students (SAS-S). The results can be proven by various indicator contained in EFA test, among others are explanation of tables as follows:

Table 1. KMO and Bartlett's Test

\begin{tabular}{lll}
\hline KMO and Bartlett's Test & \\
\hline Kaiser-Meyer-Olkin Measure of Sampling Adequacy. & $\mathbf{8 4 7}$ \\
& Approx. Chi-Square & 2509.479 \\
Bartlett's Test of Sphericity & df & 231 \\
& Sig. & .000 \\
\hline
\end{tabular}

The KMO and Bartlett's Test table shows about the feasibility test of factor analysis on a scale. There are 6 categories that can explain the results of KMO and Bartlett's Test. KMOs with values $>80 \%$ (good), between 60\% -80\% (enough) and below 60\% (bad) (Gudono, 2016).

Based on these results, it is known that $\mathrm{KMO}>0.5$ value is 0.847 or more than $80 \%$ which is meritorius / good. KMO close to 1 indicates that the data or samples used are sufficient to test the factor analysis (Yong \& Pearce, 2013). Furthermore, it can also be seen from the P-Value Barlett's Test of 0.000 which shows $<0.05$ which means that the model factor formed is feasible to use.

Furthermore, it can be seen in table 2 that explains the value of the extraction community. It can be seen that the 22 items maintained have an average value of $>0.50$ This shows that all items formed can be feasible to use as a determination of the number of structure factor that is formed.

Table 2. Communalitoes

\begin{tabular}{cc|cc}
\hline Item & Extraction & Item & Extraction \\
\hline 1 & .743 & 12 & .744
\end{tabular}




\begin{tabular}{cc|cc}
2 & .692 & 13 & .730 \\
3 & .669 & 14 & .592 \\
4 & .561 & 15 & .571 \\
5 & .545 & 16 & .633 \\
6 & .636 & 17 & .620 \\
7 & .638 & 18 & .664 \\
8 & .737 & 19 & .655 \\
9 & .710 & 20 & .772 \\
10 & .626 & 21 & .793 \\
11 & .780 & 22 & .616 \\
\hline
\end{tabular}

Tabel 3. Total Variance Explained

\begin{tabular}{|c|c|c|c|c|c|c|c|c|c|}
\hline \multirow{2}{*}{$\begin{array}{c}\text { Compo } \\
\text { nent }\end{array}$} & \multicolumn{3}{|c|}{ Initial Eigenvalues } & \multicolumn{3}{|c|}{$\begin{array}{l}\text { Extraction Sums of Squared } \\
\text { Loadings }\end{array}$} & \multicolumn{3}{|c|}{$\begin{array}{l}\text { Rotation Sums of Squared } \\
\text { Loadings }\end{array}$} \\
\hline & Total & $\begin{array}{c}\% \text { of } \\
\text { Variance }\end{array}$ & $\begin{array}{l}\text { Cumulati } \\
\text { ve } \%\end{array}$ & Total & $\begin{array}{c}\% \text { of } \\
\text { Variance }\end{array}$ & $\begin{array}{l}\text { Cumulat } \\
\text { ive } \%\end{array}$ & Total & $\begin{array}{c}\% \text { of } \\
\text { Variance }\end{array}$ & $\begin{array}{l}\text { Cumulati } \\
\text { ve } \%\end{array}$ \\
\hline 1 & 6.422 & 29.191 & 29.191 & 6.422 & 29.191 & 29.191 & 2.869 & 13.040 & 13.040 \\
\hline 2 & 2.472 & 11.237 & 40.428 & 2.472 & 11.237 & 40.428 & 2.834 & 12.882 & 25.922 \\
\hline 3 & 1.902 & 8.646 & 49.074 & 1.902 & 8.646 & 49.074 & 2.719 & 12.357 & 38.279 \\
\hline 4 & 1.631 & 7.415 & 56.489 & 1.631 & 7.415 & 56.489 & 2.667 & 12.122 & 50.401 \\
\hline 5 & 1.239 & 5.633 & 62.122 & 1.239 & 5.633 & 62.122 & 1.881 & 8.549 & 58.950 \\
\hline 6 & 1.062 & 4.828 & 66.949 & 1.062 & 4.828 & 66.949 & 1.760 & 7.999 & 66.949 \\
\hline
\end{tabular}

After can see the magnitude of the communality of table 2, the can consider the determination of the number of structures factor formed from the 22 items of the SAS-S scale by looking at the value of eigenvalues. The minimum eigenvalues that should be achieved to determine the factor is $\geq 1.0$ (Pangalila \& Budiarto, 2017). The result of analysis shows that there are six factors that meet the criteria of eigenvalue value $\geq 1.0$ (Table 3 ). The number of components formed is the number of structure factor that is formed from the smartphone addiction scale for students (SAS-S).

Based on the number is known 6 structure factor that is formed. Having known the number of strong factors that form the data note the items SAS-S are arranged in the factor. Each item is an item that has avalue loading factor $>0.50$. Thus can be seen in the table on table 4 . Rotaed Component Matrix that each factor has a number of different items.

Table 4. Rotaed Component Matrix

\begin{tabular}{|c|c|c|c|c|c|c|}
\hline \multirow{2}{*}{ Statements } & \multicolumn{6}{|c|}{ Component } \\
\hline & 1 & 2 & 3 & 4 & 5 & 6 \\
\hline I will try and be ready to use my smartphone for a long time & .830 & & & & & \\
\hline
\end{tabular}




\section{COUNS-EDU}

Vol.3, No.3, 2018

Available online: http://journal.konselor.or.id/index.php/counsedu
A.Maulani Habibi, Sigit

Sanyata

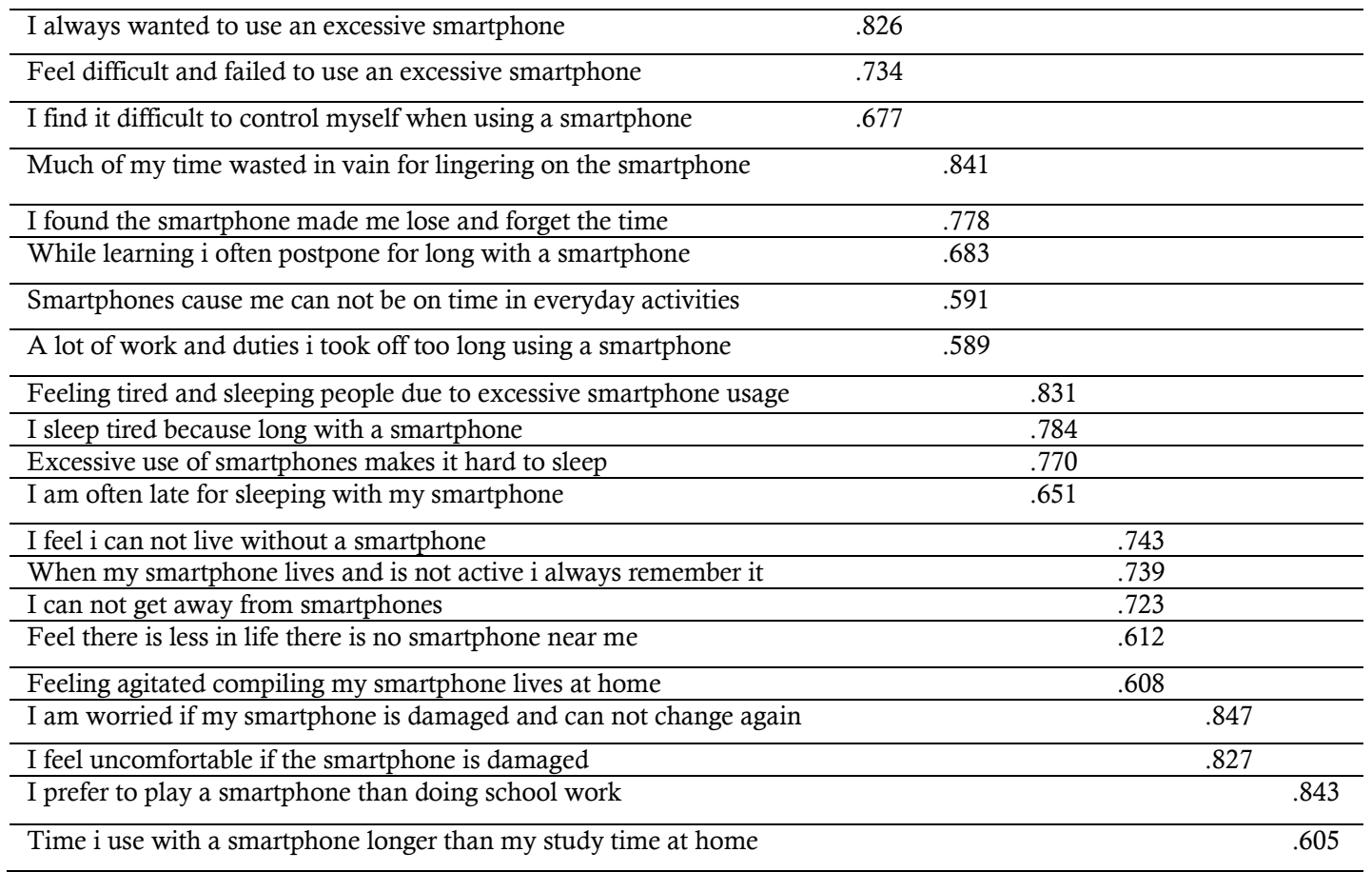

Rotated Component Matrix in Table. 4 it can be clearly seen that the value of the loading factor of each variable has been formed well and in accordance with the clear structure. The loading factor rating on the smartphone addiction scale for student (SAS-S) has a value $>0.50$, this can mean all items / variables can be used. Furthermore, these factors can be given the name of each factor formed. In order to strengthen the development of SAS-S scale is also conducted reliability test. The SAS-S reliability test is performed measurement by Alpha Cronbach's. results from output Alpha Cronbach's are presented below:

Table 5. Reliability

\begin{tabular}{ll}
\hline \multicolumn{2}{c}{ Reliability Statistics } \\
\hline Cronbach's Alpha & N of Items \\
\hline .879 & 22 \\
\hline
\end{tabular}

Based on the above table, the Alpha Cronbach's value on 22 SAS-S deck items of 0.879 indicates greater than $>0.7$, this indicates that SAS-S can be used and declared reliable.

This study is a preliminary study on the development of smartphone addiction for student (SASS). This preliminary study was conducted by performing analysis factor with exploratory factor analysis (EFA). The EFA results show that the addiction scale has six very powerful structures factor with the loading factor value of each variable having a magnitude of $>0.50$. Based on the EFA test there are several items of scale that must be eliminated to reduce the number of items from 32 items to 22 items scale of valid and reliable.

Here are the names of factors on the smartphone addiction scale for students (SAS-S) (1) Loss of control: students are not able to control themselves or control themselves while using a smartphone. (2) Time loss: excessive use smartphone causes students to lose time in vain. (3) Sleeping disorders: lingering with the smartphone causes disruption of student rest time, which is characterized by difficulty sleeping and difficulty to get up faster. (4) Can not be without a smartphone: students are always thinking of a 
smartphone and feeling lost when the smartphone is away from it. (5) Changes in feelings: the emergence of feelings of inner discomfort that cause emotional changes in him. (6) Concerned smartphone: always concerned smartphone than the task and responsibilities as a student.

These six structures are the result of literature review conducted by researchers through the operation of the following components of smartphone addiction:

\section{Excessive Use}

Smartphone addiction in students is an excessive behavior in the use of smartphones. This behavior can be characterized by the amount of time and everyday activities become disturbed and the appearance of abandonment behavior on the basic needs of human life such as eating, drinking and sleeping becomes disrupted.

\section{Withdrawal Effect}

Students with smartphone addiction bring out feelings of discomfort to themselves with feelings of anxiety, anxiety and impatience when the use of a smartphone can not afford to do. This is due to various situations and circumstances that occur, such as left at home and run out of smartphone battery. The impact of this is that students always think of their smartphones even though they are virtually unusable.

\section{Loss of Control}

Students feel the difficulty in controlling themselves against the use of smartphones this can be marked by students always try but fail to avoid or reduce from usage excessive smartphone. This is because in individuals with a smartphone addiction can cause him to difficult to let go or avoid such behavior.

These six factor structures are operational from the addiction component of smartphones and internet addiction. Many other studies also make different structures in research such as research conducted by (Kwon et al., 2013) make the structure factor / cpmponent smartphone addiction in Smartphone addiction scale (SAS) is (1) disturbance of everyday life. (2) positive anticipation. (3) withdrawal. (4) cyber oriented relationship. (5) Excessive use. (6) tolerance. The difference with the results of research conducted by kwon is the existence of different components that are component cyber oriented on relationship and postive anticipation. This component is not included in the research because this component only focuses on one of the addictions contained in the smartphone that is addicted to chat. While the smartphone addiction is the same thing with internet addiction that causes people to become addicted in some ways.

There are three subtypes of problems that occur when people are always online in front of their computer or Smartphones are: Excessive individuals in the game (excessive gaming), preoccupation with the matter concerned with sexual preoccupations (cybersex) and likes to chat (text massaging) (Block, 2008). This is also in line with (Emanuel et al., 2015) opinion that explains that people are not addicted to smartphones but they are addicted to the information, entertainment and personal connections available in smartphones, such as facebook, text messages, twitter, games, cybersex and many social networks others. The number of possible problems arising from the addiction of this smartphone makes us need to detect the level of student's smartphone addiction.

\section{Conclusions}

This study aims to develop a scale of smartphone addiction for students (SAS-S). Based on the result of factor analysis, there are a number of aborted items because they do not meet the minimum limit of the predetermined loading factor. The number of items from the EFA analysis result is 22 points out of the 32 items that have been submitted. This scale can be used to measure smartphone addiction rate of high school students in Indonesia. This scale has been tested and declared valid and reliable. Since this study is a preliminary study, further research is expected to involve more samples and can use better psychometry.

\section{Acknowledgments}

This study is an extraction of the first author's thesis and co-author by Dr. Sigit Sanyata. The authors are also grateful to the Rector of Universitas Negeri Yogyakarta, Prof. Dr. Sutrisna Wibawa. M.Pd., Mr. Chairman Prodi Guidance and Counseling Postgraduate UNY Dr. Moh Farozi and Lectures UNY Guidance and Counseling. 


\section{References}

Bian, M., \& Leung, L. (2015). Linking Loneliness, Shyness, Smartphone Addiction Symptoms, and Patterns of Smartphone Use to Social Capital. Social Science Computer Review, 33(1), 61-79. https://doi.org/10.1177/0894439314528779

Block, J. J. (2008). Issues for DSM-V: Internet addiction. American Journal of Psychiatry, 165(3), 306-307. https://doi.org/10.1176/appi.ajp.2007.07101556

Choi, J., Rho, M. J., Kim, Y., Yook, I. H., Yu, H., Kim, D., \& Choi, Y. (2017). Smartphone dependence classification using tensor factorization, 1-12. https://doi.org/10.1371/journal.pone.0177629

Demirci, K., Orhan, H., Demirdas, A., Akpinar, A., \& Sert, H. (2014). Validity and Reliability of the Turkish Version of the Smartphone Addiction Scale in a Younger Population. Klinik Psikofarmakoloji Bulteni, 24(3), 226-234. https://doi.org/10.5455/bcp.20140710040824

Dewi, N., \& Trikusumaadi, S. K. (2016). Bahaya Kecanduan Internet dan Kecemasan Komunikasi terhadap Karakter Kerja Sama pada Mahasiswa. Jurnal Psikologi, 43(3), 220-230. https://doi.org/http://doi.org/10.22146/jpsi.16829

Duke, É., \& Montag, C. (2017). Smartphone addiction, daily interruptions and self-reported productivity. Addictive Behaviors Reports, 6(October 2016), 90-95. https://doi.org/10.1016/j.abrep.2017.07.002

Emanuel, R., Bell, R., Cotton, C., Craig, J., Drummond, D., Gibson, S., ... Williams, A. (2015). The Truth About Smartphone Addiction. College Student Journal, 49(2), 291. https://doi.org/http://dx.doi.org/10.1016/j.chb.2015.04.036

Gaol, N. tua L., \& Lin, J. (2017). An initial study in the development of International Postgraduate Students Academic Stress Scale ( IPSASS ). The International Journal of Counseling and Education Vol.2, 2(4), 174-184. https://doi.org/DOI: https://doi.org/10.23916/0020170212040 Received

Gudono. (2016). Analisis Data Multivariat. In Statistik. Yogyakarta: BPFE.

Jocom, N. (2013). Peran Smarthphone dalam Menunjang Kinerja Karyawan Bank Prismadana (Studi Pada Karyawan Bank Prismadana Cabang Airmadidi). Journal Acta Diurna, 1(I), 1-24. Retrieved from http://garuda.ristekdikti.go.id/journal/article/15526

Karuniawan, A., \& Cahyanti, I. Y. (2013). Hubungan antara Academic Stress dengan Smartphone Addiction pada Mahasiswa Pengguna Smartphone. Jurnal Psikologi Klinis Dan Kesehatan Mental, 2(1), 16-21.

Kwon, M., Kim, D.-J., Cho, H., \& Yang, S. (2013). The Smartphone Addiction Scale: Development and Validation of a Short Version for Adolescents. PLoS ONE, 8(12), e83558. https://doi.org/10.1371/journal.pone.0083558

Lee, H., Ahn, H., Choi, S., \& Choi, W. (2014). The SAMS: Smartphone addiction management system and verification. Journal of Medical Systems, 38(1). https://doi.org/10.1007/s10916-013-0001-1

Lin, Y. H., Chang, L. R., Lee, Y. H., Tseng, H. W., Kuo, T. B. J., \& Chen, S. H. (2014). Development and validation of the Smartphone Addiction Inventory (SPAI). PLoS ONE, 9(6). https://doi.org/10.1371/journal.pone.0098312

Matar Boumosleh, J., \& Jaalouk, D. (2017). Depression, anxiety, and smartphone addiction in university students- A cross sectional study. PLoS ONE, 12(8), 1-15. https://doi.org/10.1371/journal.pone.0182239

Padwa, H., \& Cunhingham, J. (2010). Addiction: A Reference Encyclopedia. Addiction. ABC-CLIO, LLC.

Pangalila, S., \& Budiarto, Y. (2017). Factor analysis of $\mathrm{r}$ otter' s interpersona 1 trust scale. Humanitas, $14(2), 150-163$.

Rahmayani, I. (2015). Indonesia Raksasa Teknologi Digital Asia. Kementrian Komunikasi dan Informatika Republik $\quad$ Indonesia. $\quad$ Retrieved from https://www.kominfo.go.id/content/detail/6095/indonesia-raksasa-teknologi-digitalasia/0/sorotan_media

Smith, M., Robinson, L., \& Segal, J. (2017). Smartphone Addiction Tips for Breaking Free of Compulsive Smartphone Use. Retrieved from https://www.helpguide.org/articles/addictions/smartphoneaddiction.htm

Wahyuningsih, H. (2009). Validitas Konstruk Alat Ukur Spirituality Orientation Inventory (SOI). Jurnal Psikologi, 36(2), 116-129.

West, R., \& Brown, J. (2013). Theory of Addiction Second Edition. New Delhi, India: John Wiley\&Sons, Ltd. Yildiz, M. A. (2017). Emotion regulation strategies as predictors of internet addiction and smartphone 
addiction in adolescents. Journal of Educational Sciences and Psychology, VII (LXIX)(1), 66-79. Retrieved https://search.proquest.com/docview/1908419307?accountid=9851\%5Cnhttp://tf5lu9ym5n.search .serialssolution.com?ctx_ver=Z39.88-2004\&ctx_enc=info:ofi/enc:UTF-

8\&rfr_id=info:sid/ProQ\%3Aeducation\&rft_val_fmt=info:ofi/fmt:kev:mtx:journal\&rft.genre=article \&rft.jt

Yong, A. G., \& Pearce, S. (2013). A Beginner's Guide to Factor Analysis : Focusing on Exploratory Factor Analysis. Tutorials in Quantitative Methods for Psychology, 9(2), 79-94. https://doi.org/10.20982/tqmp.09.2.p079 